\title{
ANALYSIS OF IMMUNOGLOBULIN LEVELS AFTER EXPOSURE OF COW'S MILK PROTEIN IN MICE
}

\author{
Risa Etika ${ }^{1}$, Reza Gunadi Ranuh ${ }^{1}$, Alpha Fardah Athiyyah ${ }^{1}$, Andy Darma ${ }^{1}$, Subijanto Marto \\ Sudarmo $^{*}$, Suwarno ${ }^{2}$ \\ ${ }^{I}$ Department of Child Health, Dr. Soetomo Hospital, Faculty of Medicine, Universitas Airlangga, Surabaya, \\ Indonesia \\ ${ }^{2}$ Virology and Immunology Laboratory, Faculty of Veterinary, Universitas Airlangga \\ *subijanto.sudarmo@gmail.com \\ https://doi.org/10.34302/crpjfst/2019.11.5.10 \\ Article history: \\ Received: \\ 9 March 2019 \\ Accepted: \\ 20 September 2019 \\ Keywords: \\ Allergen; \\ Pregnant Balb/c mice; \\ Neonates Balb/c mice; \\ Immunoglobulin levels.

\begin{abstract}
This research aimed to analize immunoglobulin levels after exposure of cow's milk protein in mice. We conducted a true experiment with a posttest-only control group method. This experiment used female Balb/C mice and neonate mice (pregnant mice 10 weeks old $n=15$, neonatal mice 2 weeks old). The sample was divided into low dose group (1 mg CMP per gram weight of mice), high dose group (10 $\mathrm{mg}$ CMP per gram weight of mice) and control group that consisted 5 pregnant mice respectively. The cow's milk protein allergens were induced in pregnant mice. We took blood from the pregnant mice, and their fetuses were taken for subclass immunoglobulin examination (Ig A, IgM, IgE, Ig G) by using an ELISA (Enzyme-Linked Immunosorbent Assay) kit. In low dose group we found a significant increase $(p<0,05)$ in IgG-1, IgG-2a, and IgG-2b levels in pregnant mice and IgG-1, IgG-2a, IgG-2b, and IgG-3 in neonate mice which described in table 1 . While for the high dose group described in table 2, similar results occurred in IgG-1, IgG-2a, and IgG-3 levels $(\mathrm{p}<0.05)$ in pregnant mice and IgG- 1 , IgG- $2 \mathrm{a}, \operatorname{IgG}-2 \mathrm{~b}$, and $\mathrm{IgG}-3$ in neonate mice. In high-dose group we also found an increase in $\operatorname{IgA}, \operatorname{IgM}$, and $\operatorname{IgE}(\mathrm{p}<0.05)$ in either the neonate or pregnant mice. However, in low dose group there was only a significant increase in $\operatorname{IgM}(\mathrm{p}=0.004)$ and $\operatorname{IgE}$ $(\mathrm{p}=0,000)$ in neonate mice and only $\operatorname{IgE}(\mathrm{P}=0,000)$ in pregnant mice. In conclusion, in low dose group we found a significant increase in IgG-1, IgG-2a, IgG-2b in both pregnant and neonate mice, IgG-3 and IgE in pregnant mice, IgM and $\operatorname{IgE}$ in neonate mice. While for the high dose group similar results occurred in IgG-1, IgG-2a, IgG-3, IgA, IgM, and IgE
\end{abstract} \\ levels in both pregnant and neonate mice and $\mathrm{IgG}-2 \mathrm{~b}$ in neonate mice.
}

\section{Introduction}

Allergy is a health problem with a high prevalence. In the human population, the prevalence of allergy has reached $20 \%$, with $5 \%-15 \%$ occurring in children. In Southeast Asia, the prevalence of allergy reached $3.3 \%$ in children (Platts-Mills et al., 2003). While the prevalence is getting higher, efforts to prevent allergy is yet to be optimized, and the immunology process of in utero prevention has not been understood (Jones, Holloway, and Warner, 2000; Boyle, Robins-Browne, and Tang, 2006; Fusaro et al., 2009). Today, suspected allergic events are associated with the fetus's exposure to allergens, but this has yet to be explained. Some studies suggest that the child of a pregnant mother whose family has a history of dust mite allergy may become allergic to dust mites while exposure to cat hair 
may induce tolerance to cat hair within the child (Prescott et al., 2003). It is predicted that different doses and types of allergen will induce different immune responses from the fetus. A study shows that fetal dendritic cells do not express the Th2 allergen, but they express the Th1 allergen (Platts-Mills et al., 2003). This leads to a discussion on how to treat allergy and whether mothers should expose allergens to their child to prevent allergies from developing or avoid them. Allergy is a chronic disease that can alter the growth and development of the child. Therefore, an experiment on pregnant $\mathrm{Balb} / \mathrm{C}$ mice is conducted exposing them to low-dose and high-dose cow's milk protein allergen to analize immunoglobulin levels after exposure of cow's milk protein in mice (Kunert and Lavitska, 2001; Prescott et al., 2003; LaraVilloslada, Olivares, and Xaus, 2005).

\section{Materials and methods}

We conducted a true experiment with a posttest-only control group method to analize immunoglobulin levels after exposure of cow's milk protein in mice.

\subsection{Animals}

The study was conducted in the Virology and Immunology Laboratory, Department of Microbiology, Airlangga University, Surabaya, East Java.

This experiment used female Balb/C mice and neonates (pregnant mice 10 weeks old $\mathrm{n}=15$, neonatal mice 2 weeks old) acquired from the Farma Center of Veterinary, Surabaya. All the animals were inspected by a veterinary consultant to ensure pregnancy and the neonates' health condition. Animals were excluded if they were pregnant with fetuses with congenital disorders, have differences in meal behavior, or show signs of sickness such as decreased weight, breathing patterns, and diarrhea. Cow's milk protein allergens were induced in pregnant mice. After the pregnant mice gave birth, the neonates were kept for two weeks before having their blood taken, and the serum of both the female mice and their fetuses were examined. The samples were homogeneous in gender, age, and weight. The sample was divided into low dose group (1 mg CMP per gram weight of mice), high dose group (10 mg CMP per gram weight of mice) and control group. Then the data were analyzed using inferential statistics to achieve the research objectives.

\subsection{Cows Milk Protein Allergen}

Materials used were cow's milk protein allergen (Indoor Biotechnologies, Natural Bos d5 (NA-BD5-1). The cow's milk protein allergens were administered intraperitoneal in pregnant mice $5 \mathrm{mg} / 5 \mathrm{ml}$ : low dose $1 \mathrm{mg}$ CMP per gram weight of mice (Jones, Holloway, and Warner, 2000; Kunert and Lavitska, 2001; Prescott et al., 2003; Lara-Villoslada, Olivares, and Xaus, 2005). The high dose used the same reagent with 10 times the low dose.

\subsection{ELISA}

Immunoglobulin was analyzed using an $\mathrm{IgG}$, IgM, and IgA ELISA kit with the Sandwich method. The ELISA kit (Ig isotyping Mouse Instant: Thermo Fisher Scientific company, catalog number 88-50660-22) was used to examine the optical density (OD) of IgG1, IgG2a, IgG2b, IgG3, IgM, IgA and IgE.

The $80 \mathrm{ml}$ serums were collected into a microplate tube and processed by duplo. A standard $20 \mu \mathrm{l}$ solution of $\operatorname{IgE}$ with a titer of 0 , $50,100,200,500$, and 1000 was added into each tube, commencing to the A 1 and 2 until the $\mathrm{G} 1$ and 2 columns. The microplate was incubated for an hour in room temperature and then washed three times with buffer washing. Then $100 \mu$ of HRP enzyme was added to each tube. The microplate was then incubated for an hour and washed with buffer washing. Next, $100 \mu \mathrm{l}$ of TMB was added and incubated for 30 minutes.

Absorbant value was analyzed using the 450 $\mathrm{nm}$ wavelength of the ELISA reader and then interpreted by linear regression analysis.

\subsection{Statistics Analysis}

The experiment was analyzed using ANOVA homogeneity test and Kolmogorov- 
Smirnoff and normal probability plot for normality test for normal distribution. For testing differences between each group, we used ANOVA for normal distributed data and Kruskal Wallis A, Brown-Forsythe, and MannWhitney for abnormal distributed data.

\section{Results and discussions}

\subsection{Results}

In low dose group we found a significant increase in IgG-1, IgG-2a, and IgG-2b levels in pregnant mice $(\mathrm{p}<0.05)$ and $\operatorname{IgG}-1$, IgG-2a, $\mathrm{IgG}-2 \mathrm{~b}$, and $\mathrm{IgG}-3(\mathrm{p}<0,05)$ in neonate mice which described in table 1 . While for the high dose group described in table 2, similar results occurred in IgG-1, IgG-2a, and IgG-3 levels $(\mathrm{p}<0.05)$ in pregnant mice and $\mathrm{IgG}-1, \operatorname{IgG}-2 \mathrm{a}$,
IgG-2b, and IgG-3 in neonate mice $(\mathrm{p}<0.05)$. Between high-dose and low-dose group, we found significant differences in $\mathrm{IgG}-1$, IgG-2a, $\mathrm{IgG}-2 \mathrm{~b}$, and $\mathrm{IgG}-3$ in neonate mice (p(rt) $<0.05$ ) and IgG-1, IgG-2a, and IgG-2b in pregnant mice $(p(r-t)<0.05)$. In high-dose group we found an increase in $\operatorname{IgA}, \operatorname{IgM}$, and $\operatorname{IgE}$ $(\mathrm{p}<0.05)$ in either the neonate or pregnant mice. However, in low dose group there was only a significant increase in $\operatorname{IgM}(\mathrm{p}=0.004)$ and $\operatorname{IgE}$ $(\mathrm{p}=0,000)$ in neonate mice and only $\operatorname{IgE}$ $(\mathrm{P}=0,000)$ in pregnant mice. In the high-dose group and the low-dose group, there was a significant increase in IgA, IgM, and IgE in either the neonate or pregnant mice $(\mathrm{p}(\mathrm{r}-$ t) $<0.05$ ).

Table 1. Immunoglobulin level after being exposed to low dose cow's milk allergen

\begin{tabular}{|c|c|c|c|c|}
\hline & \multicolumn{2}{|c|}{ Low Dose Group (p) } & \multicolumn{2}{|c|}{ Control Group } \\
\hline & Pregnant mice & Neonate mice & Pregnant mice & Neonate mice \\
\hline IgG-1 & $\begin{array}{l}1.85 \pm 0.07 \\
(p=0.000)\end{array}$ & $\begin{array}{l}1.90 \pm 0.08 \\
(p=0.004)\end{array}$ & $1.26 \pm 0.07$ & $0.18 \pm 0.03$ \\
\hline $\operatorname{IgG}-2 \mathrm{a}$ & $\begin{array}{l}2.66 \pm 0.04 \\
(p=0.000)\end{array}$ & $\begin{array}{l}2.88 \pm 0.23 \\
(p=0.000)\end{array}$ & $1.41 \pm 0.05$ & $1.48 \pm 0.18$ \\
\hline $\operatorname{IgG}-2 b$ & $\begin{array}{l}3.38 \pm 0.08 \\
(p=0.000)\end{array}$ & $\begin{array}{l}2.87 \pm 0.42 \\
(p=0.001)\end{array}$ & $2.58 \pm 0.06$ & $1.95 \pm 0.18$ \\
\hline IgG-3 & $\begin{array}{l}0.47 \pm 0.14 \\
(p=0.078)\end{array}$ & $\begin{array}{l}2.09 \pm 0.47 \\
(p=0.000)\end{array}$ & $0.36 \pm 0.04$ & $0.09 \pm 0.01$ \\
\hline $\operatorname{IgA}$ & $\begin{array}{l}0.16 \pm 0.05 \\
(p=0.749)\end{array}$ & $\begin{array}{l}0.12 \pm 0.03 \\
(p=0.192)\end{array}$ & $0.15 \pm 0.09$ & $0.10 \pm 0.04$ \\
\hline $\operatorname{IgM}$ & $\begin{array}{l}1.01 \pm 0.05 \\
(p=0.184)\end{array}$ & $\begin{array}{l}0.73 \pm 0.10 \\
(p=0.004)\end{array}$ & $1.16 \pm 0.22$ & $0.24 \pm 0.08$ \\
\hline $\operatorname{IgE}$ & $\begin{array}{c}183.21 \pm 5.91 \\
(p=0.000)\end{array}$ & $\begin{array}{c}109.04 \pm 10.61 \\
(p=0.000)\end{array}$ & $21.89 \pm 0.84$ & $22.37 \pm 3.01$ \\
\hline
\end{tabular}

Table 2. Immunoglobulin level after being exposed to high dose cow's milk allergen

\begin{tabular}{|c|c|c|c|c|}
\hline & \multicolumn{2}{|c|}{ High Dose Group $(\mathrm{p})$} & \multicolumn{2}{|c|}{ Control Group } \\
\hline & Pregnant mice & Neonate mice & Pregnant mice & Neonate mice \\
\hline IgG-1 & $\begin{array}{l}1.49 \pm 0.04 \\
(p=0.000)\end{array}$ & $\begin{array}{l}1.31 \pm 0.09 \\
(p=0.004)\end{array}$ & $1.26 \pm 0.07$ & $0.18 \pm 0.03$ \\
\hline IgG-2a & $\begin{array}{l}1.33 \pm 0.46 \\
(p=0.688)\end{array}$ & $\begin{array}{l}0.76 \pm 0.17 \\
(p=0.000)\end{array}$ & $1.41 \pm 0.05$ & $1.48 \pm 0.18$ \\
\hline IgG-2b & $\begin{array}{l}2.68 \pm 0.05 \\
(p=0.009)\end{array}$ & $\begin{array}{l}2.39 \pm 0.12 \\
(p=0.001)\end{array}$ & $2.58 \pm 0.06$ & $1.95 \pm 0.18$ \\
\hline IgG-3 & $\begin{array}{l}0.45 \pm 0.05 \\
(p=0.007)\end{array}$ & $\begin{array}{l}0.20 \pm 0.05 \\
(p=0.001)\end{array}$ & $0.36 \pm 0.04$ & $0.09 \pm 0.01$ \\
\hline $\operatorname{Ig} \mathrm{A}$ & $\begin{array}{l}0.32 \pm 0.05 \\
(p=0.002)\end{array}$ & $\begin{array}{l}0.04 \pm 0.03 \\
(p=0.020)\end{array}$ & $0.15 \pm 0.09$ & $0.10 \pm 0.04$ \\
\hline $\operatorname{IgM}$ & $\begin{array}{l}1.55 \pm 0.05 \\
(p=0.007)\end{array}$ & $\begin{array}{l}0.52 \pm 0.11 \\
(p=0.000)\end{array}$ & $1.16 \pm 0.22$ & $0.24 \pm 0.08$ \\
\hline $\operatorname{IgE}$ & $\begin{array}{c}192.96 \pm 7.32 \\
(p=0.000)\end{array}$ & $\begin{array}{c}124.26 \pm 9.31 \\
(p=0.000)\end{array}$ & $21.89 \pm 0.84$ & $22.37 \pm 3.01$ \\
\hline
\end{tabular}




\subsection{Discussion}

After exposure to cow's milk allergen, there were different responses from IgG2b both in pregnant mice and neonate mice and with high doses and low doses whereas for $\operatorname{IgG} 3$, significant response was only in pregnant and neonate mice with high-dose exposure and neonate mice with low-dose exposure. It can be explained in general that exposure to high doses and low doses of both pregnant and neonate mice gives the same response, meaning that the cow's milk antigen can be transferred through the placenta to the neonate and responded to by neonate plasma cells even with a lower response ability in neonate mice. Neonatal B cells express low levels of coreceptors including CD28 and CD40 ligand on Th2 or follicular $\mathrm{T}$ helper cells with their corresponding binding partners HLA-peptide, CD80/86, and CD40 on antigen-specific B cells. This limits their capacity to respond to B cells from neonates and infants aged less than two months. Hence, the immune system is immature and markedly impaired in neonates and more so in fetuses (Mcmichael, Simon, and Hollander, 2015).

Response to the exposure to high-dose cow's milk allergen occurred in IgA and $\operatorname{IgM}$ whereas for low-dose cow's milk, there was no significant increase from the control. It can be explained that the immune system remains inferior to exposure whereas the $\mathrm{IgE}$ response shows a potent allergy parameter both in pregnant mice and neonates with allergy. In food allergy, it is believed that food-specific IgE antibodies bind to high-affinity FceRI receptors on mast cells, basophils, macrophages, and dendritic cells, as well as to low-affinity FceRII receptors on macrophages, monocytes, lymphocytes, eosinophils, and platelets. When food allergens penetrate mucosal barriers and contact $\operatorname{IgE}$ antibodies bound to mast cells or basophils, histamine and other mediators that induce symptoms of immediate hypersensitivity are released ( $\mathrm{Li}$ et al., 2005)

We found significant differences in $\operatorname{IgE}$ levels between pregnant mice and neonate mice exposed to low-dose and high-dose allergens. Efforts to induce allergy tolerance in mice exposed to high-dose allergens were unsuccessful. This is contrary to a study conducted by Adel-Patient (2005), where the dose of allergens exposed did not affect $\mathrm{IgE}$ regulation. There was an increase in IgE levels both after the exposure to low-dose or highdose allergens (Adel-Patient, Ah-Leung, Creminon, Nouaille, Chatel, Langella, and Wal, 2005; Wavrin, 2015).

\section{Conclusions}

In low dose group we found a significant increase in $\operatorname{IgG}-1$, IgG-2a, IgG- $2 b$ in both pregnant and neonate mice, $\operatorname{IgG}-3$ and $\mathrm{IgE}$ in pregnant mice, $\operatorname{IgM}$ and $\operatorname{IgE}$ in neonate mice. While for the high dose group similar results occurred in IgG-1, IgG-2a, IgG-3, IgA, IgM, and $\mathrm{IgE}$ levels in both pregnant and neonate mice and IgG-2b in neonate mice.

\section{References}

Adel-Patient, K. et al. (2005). Oral administration of recombinant Lactococcus lactis expressing bovine beta-lactoglobulin partially prevents mice from sensitization, Clinical and Experimental Allergy: Journal of the British Society for Allergy and Clinical Immunology, 35(4), pp. 539-46.

Adel-Patient, K. et al. (2011). Immunological and metabolomic impacts of administration of Cry $1 \mathrm{Ab}$ protein and MON 810 maize in mouse, PLOS ONE. Edited by M. Fessler, 6(1), p. e16346.

Aichbhaumik, N. et al. (2008). Prenatal exposure to household pets influences fetal immunoglobulin E production, Clinical \& Experimental Allergy.

Boyle, R. J., Robins-Browne, R. M., and Tang, M. L. K. (2006). Probiotic use in clinical practice: what are the risks?, American Journal of Clinical Nutrition.

Briner, T. J. et al. (1993). Peripheral T-cell tolerance induced in naive and primed mice by subcutaneous injection of peptides from the major cat allergen Fel d I., Proceedings of the National Academy of Sciences of the 
United States of America, 90(16), pp. 7608-12.

Bufford, J. D. et al. (2008). Effects of dog ownership in early childhood on immune development and atopic diseases, Clinical \& Experimental Allergy, 38(10), pp. 16351643.

Fusaro, A. E. et al. (2009). Balance between early life tolerance and sensitization in allergy: dependence on the timing and intensity of prenatal and postnatal allergen exposure of the mother, Immunology, 128(1 Suppl), pp. e541-50.

Jones, C. A., Holloway, J. A., and Warner, J. O. (2000). Does atopic disease start in foetal life?, Allergy, 55(1), pp. 2-10.

Kunert, H. W. and Lavitska, E. (2001). Stresses and strains in anisotropic cubic ultra-thin overlayers, Crystal Research and Technology.

Lara-Villoslada, F., Olivares, M., and Xaus, J. (2005). The balance between caseins and whey proteins in cow's milk determines its allergenicity, Journal of Dairy Science.

Li, X. et al. (2005). A murine model of IgEmediated cow's milk hypersensitivity, Journal of Allergy and Clinical Immunology, 103(2), pp. 206-214. doi: 10.1016/s0091-6749(99)70492-6

Mcmichael, A., Simon, A. K., and Hollander, G. A. (2015). Evolution of the immune system in humans from infancy to old age, Proceedings of the Royal Society B, Biological Sciences, 282: 20143, pp. 1-9. doi: 10.1098/rspb.2014.3085

Platts-Mills, T. A. E. et al. (2003). The relevance of maternal immune responses to inhalant allergens to maternal symptoms, passive transfer to the infant, and development of antibodies in the first 2 years of life, Journal of Allergy and Clinical Immunology.

Prescott, S. L. et al. (2003). The value of perinatal immune responses in predicting allergic disease at 6 years of age, Allergy: European Journal of Allergy and Clinical Immunology. 